\title{
Citrus Viroids: Symptom Expression and Effect on Vegetative Growth and Yield of Clementine Trees Grafted on Trifoliate Orange
}

\author{
C. Vernière, Station de Recherches Agronomiques INRA-CIRAD - 20230 San Giuliano, Corsica, France; X. Perrier \\ and C. Dubois, Centre International de Recherche pour le Développement, CIRAD-FLHOR, TA50 / PS4, 34398 \\ Montpellier cédex 5, France; A. Dubois and L. Botella, Station de Recherches Agronomiques INRA-CIRAD - 20230 \\ San Giuliano, Corsica, France; C. Chabrier, CIRAD-FLHOR, BP153, 97202 Fort-de France, Martinique; \\ J. M. Bové, Institut National de la Recherche Agronomique and Université de Bordeaux 2, IBVM, Laboratoire de \\ Biologie Cellulaire et Moléculaire, BP 81, 33883 Villenave d'Ornon cedex, France; and N. Duran Vila, Departa- \\ mento de Protección Vegetal y Biotecnología, Instituto Valenciano de Investigationes Agrarias, Apartado Oficial, \\ 46113-Moncada, Valencia, Spain
}

\begin{abstract}
Vernière, C., Perrier, X., Dubois, C., Dubois, A., Botella, L., Chabrier, C., Bové, J. M., and Duran Vila, N. 2004. Citrus viroids: Symptom expression and effect on vegetative growth and yield of clementine trees grafted on trifoliate orange. Plant Dis. 88:1189-1197.

Citrus are natural hosts of five viroid species: Citrus exocortis viroid (CEVd), Citrus bent leaf viroid (CBLVd), Hop stunt viroid (HSVd), Citrus viroid III (CVd-III), and Citrus viroid IV (CVd-IV). CEVd and specific sequence variants of HSVd are the causal agents of the wellknown diseases of citrus, exocortis and cachexia. Other viroids have been found to induce different degrees of stunting. Since commercial citrus trees are commonly infected with mixtures of these viroids, only limited information is available on their effect in species other than Etrog citron. A field assay was conducted to establish the effect of each viroid on Commune clementine trees grafted on Pomeroy trifoliate orange. Infected trees were periodically monitored over a 12-year period (1990 to 2002) for symptom expression, growth, and fruit yield. Only CEVd caused bark scaling on the trifoliate orange rootstock and marked dwarfing, both characteristic of exocortis disease as initially described. In addition, very conspicuous bumps were observed in the wood of the rootstock after removing the bark. Only those HSVd variants, previously characterized as pathogenic in several cachexia-sensitive species, induced pits and gum deposits characteristic of this disease in the clementine scion. Bark cracking symptoms on the trifoliate orange rootstock were also observed. They were associated with CVd-IV, HSVd, or CEVd infection, but in the latter, they were only clearly observed in trees that showed mild scaling. Other abnormalities (deep pits, crests, and gummy pits) were not associated with viroid infection. No specific symptoms resulted from infection with CBLVd and CVd-III. HSVd, CVdIV, and CBLVd had little or no effect in growth and yield, whereas CEVd and CVd-III caused a significant reduction of growth and yield, which became more pronounced over time with CEVd infection. Yield reduction was associated mainly with loss of production of large fruits. In general, there was a good correlation between reduction in vegetative growth and yield.
\end{abstract}

Additional keywords: xyloporosis

Citrus exocortis disease was described in 1948 as a bark shelling or scaling disorder affecting trees grown on the trifoliate orange (Poncirus trifoliata (L.) Raf.) rootstock (12), and soon afterward graft transmission was demonstrated $(2,3)$. The dis-

Corresponding author: Núria Duran Vila

E-mail: nduran@ivia.es

This work is dedicated to the memory of Robert Vogel (1929-2002).

Current address of Christian Vernière: Centre International de Recherche pour le Développement, CIRAD-FLHOR, TA50/PS4, 34398 Montpellier cédex 5, France.

Accepted for publication 12 May 2004.

Publication no. D-2004-0824-01R

C 2004 The American Phytopathological Society groups (CEVd, CVd-I, CVd-II, CVd-III, and CVd-IV) according to (i) their electrophoretic migration in 5\% sequential polyacrylamide gel electrophoresis (sPAGE), (ii) sequence homology determined by molecular hybridization against specific cDNA probes, (iii) host range, and (iv) symptoms on the Etrog citron indicator (10). The sequencing information available today shows that the proposed groups were consistent with the viroid species concept (Table 1) proposed by the International Committee on Taxonomy of Viruses (14). Recently, an additional viroid species, tentatively named CVd-OS, has been reported in Japan (22).

Indexing tests conducted in citrus growing areas throughout the world indicate that all commercial species and varieties can be infected with viroids and therefore are considered susceptible. Whereas most citrus species are symptomless carriers, some species used commercially as rootstocks or scions are sensitive to specific viroids and develop symptoms when infected. At present, Koch's postulates have only been fulfilled for two well-known citrus diseases, exocortis and cachexia.

Following the first description of citrus viroids other than $\mathrm{CEVd}$, it was demonstrated that specific variants of CVd-II caused the cachexia disease (40) first described in 1948 as discoloration, gumming, and browning of phloem tissues, wood pitting and bark cracking on Orlando tangelo $(C$. paradisi Macfad. $\times C$. reticulata Blanco) (6). CVd-II has been characterized as a citrus variant of Hop stunt viroid (HSVd) in which a specific 6-nucleotide motif located in the Variable (V) domain is responsible for the induction of cachexia symptoms in cachexia-sensitive hosts (30). It was subsequently demonstrated that cachexia and a similar disorder described earlier as xyloporosis in Palestine sweet lime (C. limettioides Tan.) (32) are induced by the same type of HSVd variants (31). Other citrus species sensitive to this disease are alemow (C. macrophylla Webster) and Rangpur lime (C. limonia Osbeck), which are used as rootstocks, and mandarins ( $C$. deliciosa Blanco), mandarin hy- 
brids (tangors and tangelos), clementines (C. clementina Hort. Ex Tan.), satsumas (C. unshiu (Macfad. Marc.), and kumquats (Fortunella sp.).

Each viroid species induces specific symptoms on Etrog citron (10), but only partial information is available regarding the effect of each viroid in commercial species (34). In addition, viroids have also been shown to induce different degrees of dwarfing in certain rootstock/scion combinations $(20,24,25,34,39,44)$. Here, we describe the results of an experiment initiated in 1989 in which Commune clementine trees grafted on Pomeroy trifoliate orange rootstock were inoculated with several viroid sources. Some preliminary results using the same viroid sources have been reported (43). The aim of the present study was to determine: (i) the relationship of each viroid with exocortis, cachexia, and other symptoms; and (ii) the effect of each viroid on dwarfing and yield. The rootstock/scion combination was chosen as appropriate for the observation of exocortis and cachexia symptoms and dwarfing.

\section{MATERIALS AND METHODS}

Viroid sources. Single viroid sources were selected from the viroid collection maintained at Instituto Valenciano de Investigaciones Agrarias (IVIA) on inoculated citrons (Table 1). When this assay was initiated in 1989, only limited information was available regarding the molecular characteristics of these viroids, and the isolates were chosen based on migration differences in sPAGE. The information available now is summarized below:

Citrus exocortis viroid (CEVd). CEVd117 and CEVd-129 were recovered from two field isolates (E-117 and E-129) containing other citrus viroids in addition to CEVd (9). Purified CEVd-117 and CEVd129 differed in the severity of the symp-

toms induced in citron and Gynura aurantiaca (11). Sequencing demonstrated that CEVd-117 and CEVd-129 were highly homologous to the CEVd sequences defined by Visvader and Symons (45) as class A and class B, respectively $(5,19)$.

Citrus bent leaf viroid (CBLVd). CVdIa-117 was recovered from the field isolate E-117 (9). Sequencing demonstrated that it was highly homologous to CVd-Ia reported by Semancik et al. (39) but contained a set of nucleotide changes clustered in the left of the viroid secondary structure (16). CVd-Ib, initially reported as CVaVd (36), is similar to the type strain of CBLVd (1). Since CVd-Ia and CVd-Ib differ considerably in size as a result of an insertion of 5-nucleotide clusters in the $\mathrm{T}_{\mathrm{R}}$ domain, it has been proposed that $\mathrm{CVd}$-Ia might be a derivative of CVd-Ib (21).

Hop stunt viroid (HSVd). CVd-IIa-117 was recovered from the field isolate E-117 (9) and was highly homologous to the noncachexia CVd-IIa source from California (27,39). CVd-IIb and CVd-IIc were characterized as cachexia-inducing variants containing a 6-nucleotide motif responsible for pathogenicity $(30,31)$.

Citrus viroid III (CVd-III). CVd-IIIa and $\mathrm{CV}$-IIIb were isolated from California sources (24) and differed in 11 nucleotide changes (29). CVd-IIIc and CVd-IIId were selected from Spanish sources, and their molecular characterization showed that their nucleotide sequence was highly homologous to CVd-IIIb (16; RomeroDurbán and N. Duran-Vila, unpublished results).

Citrus viroid IV (CVd-IV). CVd-IV-Ca was originally from California and has been characterized as highly homologous to type CVd-IV strain from Israel $(17,28)$.

Plant materials and inoculation. In May 1989, Pomeroy trifoliate orange seedlings were graft-inoculated with one of 12

Table 1. Single viroid sources selected to inoculate clementine trees grafted on Pomeroy trifoliate orange rootstock

\begin{tabular}{llll}
\hline Viroid species $^{\mathbf{x}}$ & Other acronyms $^{\mathbf{y}}$ & Isolate $^{\mathbf{z}}$ & References \\
\hline CEVd & & CEVd-117 & 9,19 \\
& & CEVd-129 & $5,9,11$ \\
CBLVd & CVd-I, CVaVd & CVd-Ia-117 & 9,16 \\
\multirow{2}{*}{ HSVd } & CVd-II, CCaVd, CBVd & CVd-Ib & 36 \\
& & CVd-IIa-117 & 9,27 \\
& & CVd-IIIc & 30,31 \\
CVd-III & CVd-IIIa & 30,31 \\
& & CVd-IIIb & 29 \\
& CVd-IIIc & 29 \\
CVd-IV & CVd-IIId & Unpublished results \\
\hline
\end{tabular}

${ }^{x}$ Nomenclature accepted by the International Committee on Taxonomy of Viruses: CEVd (Citrus exocortis viroid), CBLVd (Citrus bent leaf viroid), HSVd (Hop stunt viroid), CVd-III (Citrus viroid III), CVd-IV (Citrus viroid IV).

${ }^{\mathrm{y}}$ Acronyms used in the literature before the present taxonomical classification was available (only first citation is given): CVd-I and CVd-II (Citrus viroids I and II, respectively) (8), CVaVd (Citrus variable viroid) (36), CCaVd (Citrus cachexia viroid) (40), CBVd (Citrus B viroid) (7).

${ }^{\text {z }}$ Isolates CVd-Ib, CVd-IIb, CV-IIc, CVd-IIIa, CVd-IIIb, and CVd-IV-Ca were kindly provided by J. S. Semancik and C. N. Roistacher (University of California, Riverside). Isolates CEVd-117, CEVd129, CVd-Ia-117, CVd-IIa-117, CVd-IIIc, and CVd-IIId were recovered from field sources kindly provided by L. Navarro (IVIA, Valencia, Spain). viroid isolates (six plants per viroid treatment and six noninoculated controls) (Table 1). Each viroid source had been maintained in Etrog citron plants grafted on rough lemon. The Etrog citron plants had been periodically tested to verify that they contained the expected single viroid source. Buds of the Commune clementine SRA85 selection from the Corsican budwood registration program were grafted on the Pomeroy trifoliate orange seedlings, and the following year, the young trees were transplanted to a field plot of the "Station de Recherches Agronomiques INRA/CIRAD" (SRA) located at San Giuliano (Corsica, France) in a randomized block arrangement. The station is at an altitude of $47 \mathrm{~m}$ on the east coast of the island at the northern limit of the citrus area (north latitude $42^{\circ} 28^{\prime}$ and east longitude $\left.9^{\circ} 52^{\prime}\right)$. Daily mean minimum and maximum temperatures fluctuate from $5.2^{\circ} \mathrm{C}$ in January to $18.7^{\circ} \mathrm{C}$ in August and from $12.9^{\circ} \mathrm{C}$ in January to $28.4^{\circ} \mathrm{C}$ in August, respectively. Mean annual rainfall is about $850 \mathrm{~mm}$.

All the trees were indexed at least twice during a 10-year period. Two indexing methods were used: (i) biological indexing on Etrog citron followed by nucleic acid extraction and sPAGE analysis; (ii) nucleic acid extracts of clementine samples (leaves and stems) collected in July 1995 subjected to sPAGE and slot-blot hybridization analysis. Nonconforming trees, i.e., trees whose viroid patterns did not fit the indicated treatment, and those associated with problems affecting the parameters to be analyzed (snow damage occurred in winter 1996) were not taken into consideration for this study.

Two pruning operations were conducted in 1990 and 1991 to shape the trees. Since 1996 , the trees were pruned yearly as in commercial orchards, in order to open the canopy, which provides agronomical advantages (good aeration unfavorable to fungal infections, improvement of light within the tree canopy). During all these operations, tools were disinfested with a sodium hypochlorite solution between trees. Fertilization and mineral oil based pesticide applications were made following normal procedures in the region. Irrigation was applied by a microjet system.

Viroid indexing. Biological indexing. Inoculated trees were indexed using the viroid-sensitive selection 861-S1 of Etrog citron (35) grafted on Volkamer lemon (C. volkameriana Ten. \& Pasq.) rootstock. Two indicator plants per test were graftinoculated on the rootstock, and symptoms were observed 6 months after inoculation (4). Samples of young leaves and stems were further subjected to $5 \%$ sPAGE analysis.

Nucleic acid extraction and SPAGE analysis. Tissue samples (5 g) were homogenized in phenol containing extraction medium $(0.4 \mathrm{M}$ Tris- $\mathrm{HCl}, \mathrm{pH} 8.9 ; 1 \%$ 
(wt/vol) sodium dodecyl sulfate (SDS); 5 mM EDTA, pH 7.0; 4\% (vol/vol) mercaptoethanol) (38). The total nucleic acids were partitioned in $2 \mathrm{M} \mathrm{LiCl}$, and the soluble fraction was concentrated by ethanol precipitation and resuspended in TKM buffer (10 mM Tris-HCl, $\mathrm{pH} 7.4 ; 10$ $\mathrm{mM} \mathrm{KCl} ; 0.1 \mathrm{mM} \mathrm{MgCl}_{2}$ ). Aliquots of these preparations $(20 \mu \mathrm{l}$ equivalent to $300 \mathrm{mg}$ fresh weight) were subjected to sPAGE (33).

Slot-blot hybridization. Total nucleic acid preparations were obtained from clementine bark samples ( $5 \mathrm{~g}$ ) as described above. Aliquots (10 $\mu \mathrm{l}$ equivalent to 150 $\mathrm{mg}$ fresh weight) were denatured in $40 \%$ formaldehyde at $60^{\circ} \mathrm{C}$ for $15 \mathrm{~min}$, slotblotted onto the surface of positively charged nylon membranes, and immobilized by UV cross-linking. Prehybridization and hybridization were carried out in $50 \%$ formamide using digoxigenin (DIG)labeled DNA probes (26). The DIG-labeled hybrids were detected with an anti-DIGalkaline phosphatase conjugate (Fab fragments) and visualized with the chemiluminescence substrate disodium 3-(4-methoxyspiro \{1,2-dioxetane-3,2'-(5'-chloro) tricyclo [3.3.1.1 $\left.{ }^{3,7}\right]$ decan $\left.\}-4-y l\right)$ phenyl phosphate (CSPD) (Roche Diagnostics GmbH, Penzberg, Germany).

Symptom evaluation. Bark symptoms (scaling and cracking) were evaluated annually. Symptoms under the bark and on the wood were examined by lifting bark strips ( $6 \mathrm{~cm}$ long $\times 3 \mathrm{~cm}$ wide). Cachexia symptoms were examined yearly on the bark and the wood of the clementine scion beginning in 1993. Symptoms under the bark and in the wood of the rootstock were also recorded yearly since 1998. In 2002, when the experiment was terminated, the trees were decapitated $50 \mathrm{~cm}$ above the bud union, and the bark of the stumps was completely removed for a final evaluation of symptoms on the wood above and below the bud union.

Tree growth and fruit yield. Tree height, trunk circumferences of the scion and the rootstock $(10 \mathrm{~cm}$ above and below the bud line), and fruit yield were measured annually. Since the trees were pruned yearly after 1996, no additional tree height measurements were conducted until 2001 when the experiment was terminated. This last measurement allowed an estimate of the canopy volume, which was calculated as $V_{c}=4 / 3 \pi R^{3}$ ( $R$ being the radius of the canopy estimated from tree height). Fruits were harvested manually when the sugar content/acidity ratio was greater than 7.0 and fruit coloration exceeded $80 \%$, and they were then processed through a Greefa calibrator A2 (Greefa Machinebouw B.V., Geldermalsen, The Netherlands) in order to separate them according to size and estimate the weight of fruits by caliber. Data were analyzed by ANOVA using the GLM procedure of SAS (SAS Institute, Inc., Cary, NC).

The elimination of nonconforming trees (those in which the inoculated viroid was not detected or suspected of being contaminated) reduced replicates for some treatments, and the mean values were adjusted using the LSMEANS procedure of SAS. Whenever $F$ values were significant at $P<0.05$, treatment means were separated using Tukey's honestly significant difference test. In addition, each treatment mean was compared with the healthy control mean using the Dunnett test.

\section{RESULTS}

Symptoms induced by viroid infection. Bark scaling. Scaling symptoms were observed only on CEVd-infected trees (Table 2), thus confirming that CEVd is the only agent of exocortis disease as initially described. Bark scaling at the soil level was first observed 4 years after inoculation with CEVd-117 (Fig. 1A) and 5 years after inoculation with CEVd-129. When the experiment was terminated after 13 years, the symptoms induced by the two CEVd sources were still distinct. All the trees infected with CEVd-117 exhibited severe scaling of the rootstock, from the soil level to bud-union (Fig. 1B), whereas the scaling induced by CEVd-129 was more moderate (Fig. 1C). The trees infected with CEVd-129 also exhibited cracks and very conspicuous bumps, not previously reported (Fig. 1D). Bumps were more easily observed on the wood after removing the bark, with both CEVd treatments (CEVd117 and CEVd-129) (Fig. 1E). CEVd infection was also associated with poor appearance of the canopy and severe stunting (see next section).

Bark cracking. Bark cracking symptoms were observed in several treatments (Table $2)$. They were more consistently found in trees infected with CVd-IV (6 of 6) and HSVd (12 of 17), regardless of the isolate. The cracks were generally more conspicuous in trees infected with CVd-IV than in those infected with HSVd (Fig. 1F and G). On the cambial side of the bark, cracking was even more perceptible due to the presence of green streaks with protuberances that fit into depressions of the wood, which were also surrounded by green streaks that had not been described before (Fig. 1J). The green streaks fit into the shape of the cracks (Fig. 1K) and seem to be the result of chlorophyll production under the very thin bark covering the cracks. Even though bark cracking seems to be most frequently associated with CVd-IV and HSVd, it was also observed in trees infected with CEVd129. It was never found in trees infected with CBLVd or CVd-III, nor in the noninoculated controls. Small cracks were observed on some CEVd-117-infected

Table 2. Symptoms observed on Commune clementine grafted on Pomeroy trifoliate orange rootstock infected with single viroid sources

\begin{tabular}{|c|c|c|c|c|c|c|c|c|c|c|}
\hline & & & & & & \multicolumn{4}{|c|}{ Rootstock wood } & \multirow{4}{*}{$\begin{array}{c}\text { Scion } \\
\begin{array}{c}\text { Cachexia } \\
\text { symptoms }\end{array} \\
\text { No. trees }^{y}\end{array}$} \\
\hline & & \multicolumn{4}{|c|}{ Rootstock bark } & \multirow{3}{*}{$\begin{array}{c}\text { Bumps } \\
\text { No. trees }^{y}\end{array}$} & \multirow{3}{*}{$\frac{\text { Crests }}{\text { No. trees }}$} & \multicolumn{2}{|c|}{ Gummy pittingw } & \\
\hline \multicolumn{2}{|c|}{ Treatment } & \multicolumn{2}{|c|}{ Scaling } & \multicolumn{2}{|c|}{ Cracking } & & & \multirow{2}{*}{$\begin{array}{l}\text { Shoulder } \\
\text { No. trees }^{y}\end{array}$} & \multirow{2}{*}{$\begin{array}{c}\text { Lateral } \\
\text { No. trees } \\
\end{array}$} & \\
\hline Viroid $^{x}$ & Isolate & Intensity & No. trees $^{y}$ & Intensity & No. trees ${ }^{y}$ & & & & & \\
\hline Control & & - & $0 / 4$ & - & $0 / 4$ & $0 / 4$ & $2 / 4$ & $4 / 4$ & $0 / 4$ & $0 / 4$ \\
\hline \multirow[t]{2}{*}{ CEVd } & CEVd-117 & Severe & $6 / 6$ & Mild & $1 / 6^{\mathrm{z}}$ & $6 / 6$ & $1 / 6$ & $6 / 6$ & $0 / 6$ & $0 / 6$ \\
\hline & CEVd-129 & Moderate & $6 / 6$ & Moderate & $6 / 6$ & $6 / 6$ & $3 / 6$ & $5 / 6$ & $0 / 6$ & $0 / 6$ \\
\hline \multirow[t]{2}{*}{ CBLVd } & CVd-Ia-117 & - & $0 / 5$ & - & $0 / 5$ & $0 / 5$ & $2 / 5$ & $5 / 5$ & $0 / 5$ & $0 / 5$ \\
\hline & $\mathrm{CVd}-\mathrm{Ib}$ & - & $0 / 5$ & - & $0 / 5$ & $0 / 5$ & $4 / 5$ & $5 / 5$ & $0 / 5$ & $0 / 5$ \\
\hline \multirow[t]{3}{*}{ HSVd } & CVd-IIa-117 & - & $0 / 6$ & Mild & $3 / 6$ & $0 / 6$ & $1 / 6$ & $6 / 6$ & $1 / 6$ & $0 / 6$ \\
\hline & CVd-IIb & - & $0 / 5$ & Mild & $5 / 5$ & $0 / 5$ & $1 / 5$ & $5 / 5$ & $0 / 5$ & $5 / 5$ \\
\hline & CVd-IIc & - & $0 / 6$ & Mild & $4 / 6$ & $0 / 6$ & $2 / 6$ & $4 / 6$ & $0 / 6$ & $6 / 6$ \\
\hline \multirow[t]{4}{*}{ CVd-III } & CVd-IIIa & - & $0 / 6$ & - & $0 / 6$ & $0 / 6$ & $1 / 6$ & $6 / 6$ & $2 / 6$ & $0 / 6$ \\
\hline & CVd-IIIb & - & $0 / 6$ & - & $0 / 6$ & $0 / 6$ & $1 / 6$ & $6 / 6$ & $2 / 6$ & $0 / 6$ \\
\hline & CVd-IIIc & - & $0 / 6$ & - & $0 / 6$ & $0 / 6$ & $1 / 6$ & $6 / 6$ & $3 / 6$ & $0 / 6$ \\
\hline & CVd-IIId & - & $0 / 6$ & - & $0 / 6$ & $0 / 6$ & $2 / 6$ & $6 / 6$ & $0 / 6$ & $0 / 6$ \\
\hline CVd-IV & CVd-IV-Ca & - & $0 / 6$ & Severe & $6 / 6$ & $0 / 6$ & $1 / 6$ & $6 / 6$ & $1 / 6$ & $0 / 6$ \\
\hline
\end{tabular}

w Symptoms in the shoulder refer to the pronounced pitting in the bottle neck shoulder of the rootstock/scion union; lateral symptoms refer to the pitting and gumming observed along the surface of the rootstock wood.

${ }^{x}$ CEVd (Citrus exocortis viroid), CBLVd (Citrus bent leaf viroid), HSVd (Hop stunt viroid), CVd-III (Citrus viroid III), CVd-IV (Citrus viroid IV).

y Number of trees showing symptoms over the total number of trees.

${ }^{\mathrm{z}}$ In 1998, cracking was observed on 4/6 trees, then was masked by severe scaling. 
rootstocks in 1995 but were later masked by the intense scaling.

Cachexia symptoms. Seven years after inoculation, mild cachexia symptoms characterized by the presence of small pits in the wood (Fig. 1H) and gum deposits in the bark were perceptible upon lifting small portions of the clementine bark. This early observation was confirmed when the bark was totally removed when the experiment was terminated (Fig. 1I). The symptoms were only observed on the trees infected with the pathogenic isolates CVd-IIb and CVd-IIc of HSVd (Table 2), and no differences in severity be- tween the two isolates were found. Symptoms of cachexia were mild, probably because clementine is not a very sensitive host, and the cool climate of Corsica does not favor expression of severe symptoms.

Abnormalities not associated with viroid infection. Deep pits and crests. After
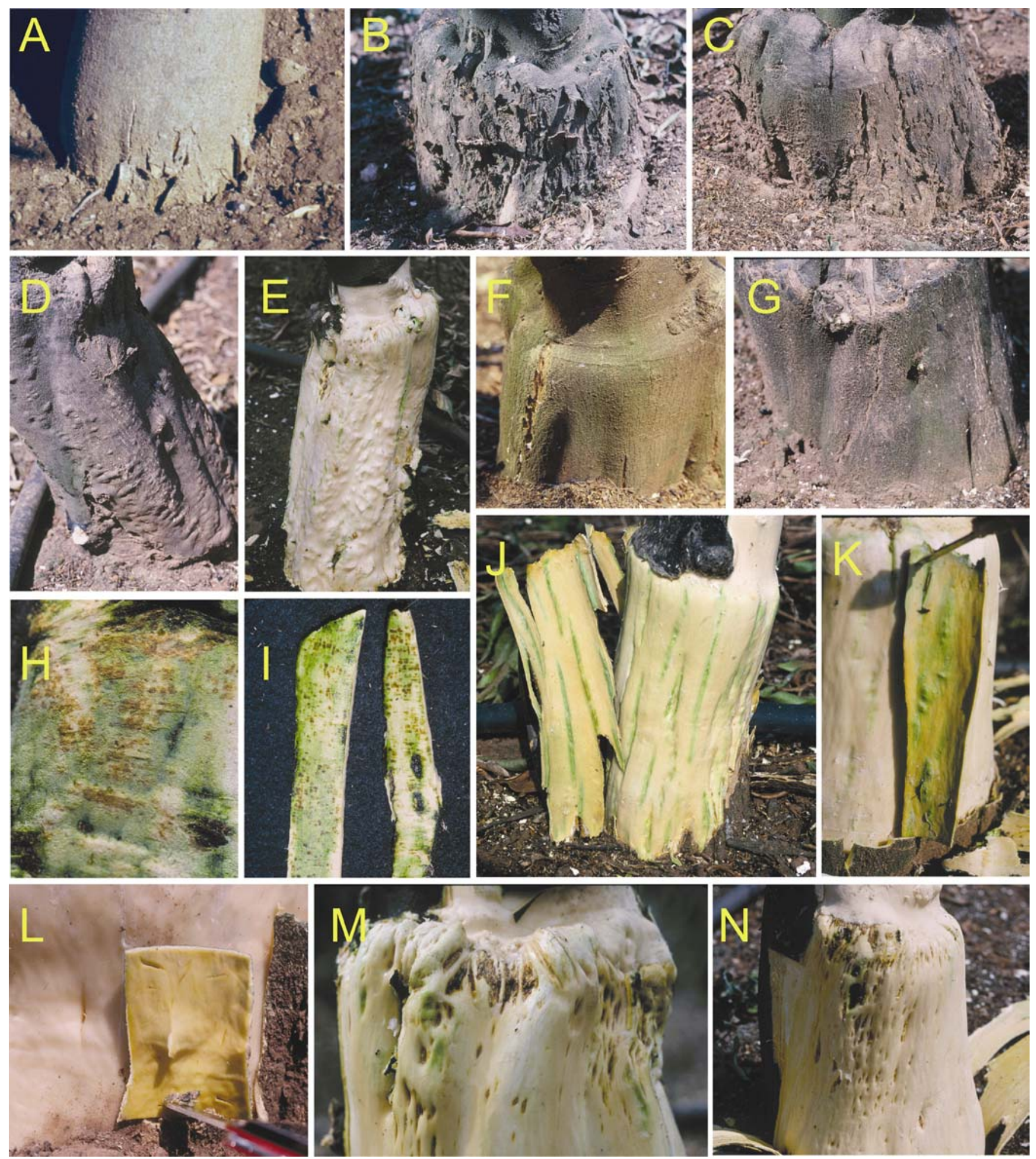

Fig. 1. Symptoms and abnormalities observed on Commune clementine grafted on trifoliate orange rootstock. A and B, Bark scaling induced by Citrus exocortis viroid (CEVd-117) in trifoliate orange 4 and 11 years after inoculation, respectively. $\mathbf{C}$ to $\mathbf{E}$, Bark cracking, scaling, and bumps induced by CEVd129 in trifoliate orange. F and G, Bark cracking in trifoliate orange induced by Citrus viroid IV (CVd-IV) and Hop stunt viroid (HSVd), respectively. H and $\mathbf{I}$, Cachexia symptoms of wood pitting and gum deposits induced by CVd-IIb and CVd-IIc isolates of HSVd in the bark of the clementine scion. J and K, Green streaks with protuberances that fit into depressions of the wood observed under cracks induced by HSVd and CVd-IV in trifoliate orange. $\mathbf{L}$ to $\mathbf{N}$, Vertical crests and gummy pits in trifoliate orange which are not associated with viroid infection. 
the bark was removed, vertical crests or pegs, which were sometimes very conspicuous (Fig. 1L), were observed on the cambial side of the trifoliate orange rootstock bark. This abnormality was observed in a few trees of each one of the treatments, as well as in the noninoculated controls (Table 2), and resembles the "deep pitting symptoms" described on the trifoliate orange rootstock of CBLVd (CVd-Ia) infected trees by Roistacher et al. (34).

Gummy pits. Clementine trees on trifoliate orange rootstock showed pronounced "bottle necks", the scion diameter being smaller than the rootstock diameter. After the bark was removed, many trees showed pronounced pitting in the bottle neck shoulder of the rootstock/scion union (Fig. $1 \mathrm{M})$. This abnormality was observed in trees of all treatments as well as in the noninoculated controls (Table 2), but it was most commonly found around areas that showed signs of wood damage. In some trees, round gummy pits were also observed along the whole surface of nondamaged wood of the trifoliate orange rootstock (Fig. 1N). These round pits containing gum pockets were similar to the "woody pitting", "gum pocket", and "gummy pitting" disorders described in Argentina, South Africa, and Australia, respectively $(13,15,18,23,37)$.

Effect of viroid infection on tree size and fruit harvest. Vegetative growth. Growth patterns are shown in Figure 2. As illustrated in Table 3, statistical analysis of the vegetative growth parameters (height, rootstock and scion circumferences) recorded from 1990 to 2001 were highly significant since 1994. There was no significant block effect for growth parameters except for rootstock circumference, where a significant difference appeared after 1997. As illustrated in Table 4, which shows the means of the parameters collected in 1996 and 2001, mean heights were considerably lower for CEVd and CVd-III, but only trees infected with isolates CEVd-117 and CVd-IIId were significantly smaller than the noninoculated control. It must be kept in mind that since the trees were pruned yearly since 1996, mean height measurements do not fully illustrate the effect of the treatments. In 1996, mean rootstock circumferences were also considerably smaller for CEVd and CVd-III treatments, but this effect was only statistically significant in trees infected with isolates CEVd-117 and CVdIIIa. The differences in rootstock growth became more conspicuous in later years, and in 2001, CEVd-117, all CVd-III isolates, and CV-IIc had induced statistically significant reductions in rootstock growth. Mean rootstock circumferences ranged from 60 to $75.1 \mathrm{~cm}$ for CVd-IIIa-infected trees and healthy controls, respectively (Table 4). Similarly, in 1996, mean scion circumferences were considerably smaller than the control for CEVd and CVd-III treatments, but the effect was only statistically significant in trees infected with isolates CVd-IIIa and CVd-IIIc (Table 4). These differences in scion growth also became more marked in later years, and in 2001 the reduction in scion growth was statistically significant for all the CEVd and CVd-III isolates. CBLVd and CVd-IV had no significant effect on tree growth. Although HSVd isolates had little or no effect, the mean rootstock and scion circumferences in 2001 were considerably
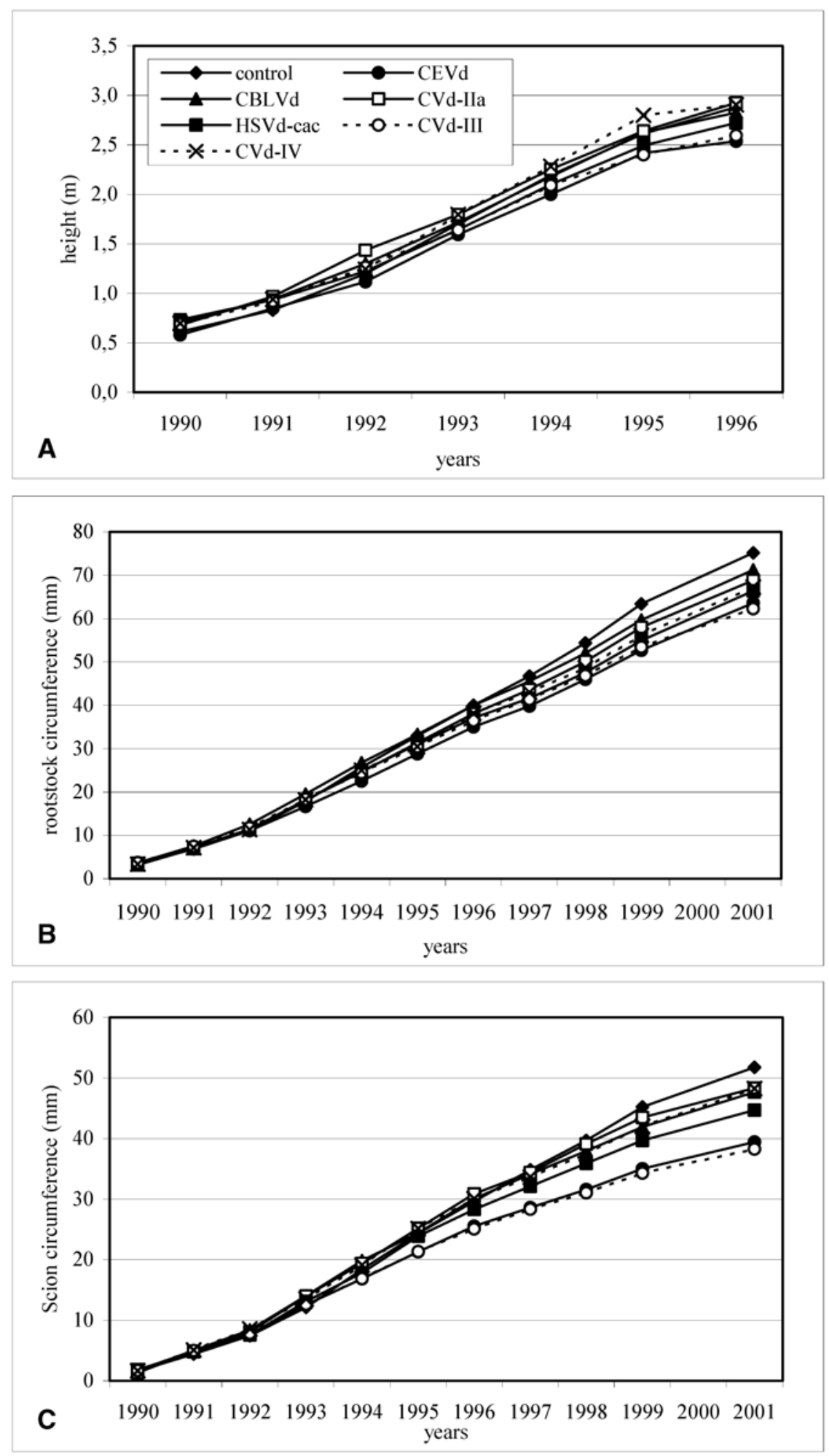

Fig. 2. Growth of Commune clementine grafted on trifoliate orange after infection with single viroids measured as: $\mathbf{A}$, height of the trees; $\mathbf{B}$, rootstock circumference; and $\mathbf{C}$, scion circumference. Curves represent the average of isolates of each viroid species. In the case of Hop stunt viroid (HSVd), cachexia isolates are represented separately (HSVd-cac is the average of isolates CVd-IIb and CVdIIc) from the non-cachexia isolate CVd-IIa. 
smaller than the control, but only significant in the case of the cachexia-inducing isolate $\mathrm{CVd}$-IIc. The reduction of vegetative growth resulted in reduction of canopy volume (Table 5). The major effect was observed in trees infected with CVd-IIId with a canopy volume 56\% (in 1996) and $61 \%$ (in 2001) of that of the uninoculated controls.

Yield and fruit size. Fruits were first harvested on most of the trees in 1992, and yearly afterward. Block effect was not statistically significant for yield measurements except for annual yields of the last 2 years (Table 3). A significant difference for annual and cumulative yields among viroid treatments was first observed in 1994 and became more conspicuous after 1996 (Table 3). Annual yields varied over the years, with patterns of annual fluctuation being similar among the different treatments (Fig. 3A). No significant difference was revealed by the Tukey HSD test in 1996, even though $F$ was significant at $P=0.01$, but CEVd and CVd-III had the strongest effect in reducing fruit production (Table 4). In 2001, trees infected by CEVd and CVd-III also gave the smallest yields, with statistical differences for CEVd-117 and CVd-IIId isolates compared to the CVdIIa isolate but not to the control. CEVd and some isolates of CVd-III were statistically separated from the control between 1997 and 2000 (data not shown). No statistical differences were found for CBLVd, HSVd, and CVd-IV, but cachexia

Table 3. Growth and yield parameters of viroid-infected Commune clementine grafted on Pomeroy trifoliate orange; sources of variation and their significance in a complete randomized block design with six replications

\begin{tabular}{|c|c|c|c|c|c|c|c|c|c|c|c|c|}
\hline & \multicolumn{12}{|c|}{ Years } \\
\hline & 1990 & 1991 & 1992 & 1993 & 1994 & 1995 & 1996 & 1997 & 1998 & 1999 & 2000 & 2001 \\
\hline \multicolumn{13}{|l|}{ Tree height (m) } \\
\hline General mean & 0.68 & 0.91 & 1.24 & 1.67 & 2.12 & 2.51 & 2.70 & - & - & - & - & - \\
\hline Residual CV (\%) & 21.0 & 12.0 & 13.0 & 11.0 & 8.0 & 7.1 & 7.6 & - & - & - & - & - \\
\hline Mean amplitude ${ }^{y}$ & 0.28 & 0.15 & 0.36 & 0.33 & 0.34 & 0.51 & 0.50 & - & - & - & - & - \\
\hline$F$ Treatment prob $>F$ & $0.3325 \mathrm{NS}^{\mathrm{Z}}$ & $0.4813 \mathrm{NS}$ & $0.0783 \mathrm{NS}$ & $0.1705 \mathrm{NS}$ & $0.0228^{*}$ & $0.0018 * *$ & $0.0021 * *$ & - & - & - & - & - \\
\hline$F$ Block prob $>F$ & 0.9454 NS & $0.5675 \mathrm{NS}$ & $0.7260 \mathrm{NS}$ & $0.1693 \mathrm{NS}$ & $0.1634 \mathrm{NS}$ & $0.0555 \mathrm{NS}$ & $0.2690 \mathrm{NS}$ & - & - & - & - & - \\
\hline \multicolumn{13}{|c|}{ Rootstock circumference $(\mathrm{cm})$} \\
\hline General mean & 3.6 & 7.2 & 11.6 & 18.1 & 24.6 & 30.8 & 37.1 & 42.1 & 48.0 & 55.2 & - & 65.6 \\
\hline Residual CV (\%) & 15.0 & 8.8 & 10.0 & 8.4 & 7.8 & 6.9 & 7.0 & 6.9 & 7.1 & 7.0 & - & 7.2 \\
\hline Mean amplitude ${ }^{\mathrm{y}}$ & 0.8 & 1.2 & 2.8 & 4.8 & 6.9 & 6.7 & 8.0 & 9.0 & 10.2 & 12.6 & - & 14.9 \\
\hline$F$ Treatment prob $>F$ & $0.5129 \mathrm{NS}$ & $0.3255 \mathrm{NS}$ & $0.0609 \mathrm{NS}$ & $0.0056 * *$ & $0.0009 * * *$ & $0.0024 * *$ & $0.0016 * *$ & $0.0006^{* * *}$ & $0.0007 * * *$ & $0.0003 * * *$ & - & $0.0004 * * *$ \\
\hline$F$ Block prob $>F$ & $0.5694 \mathrm{NS}$ & $0.9011 \mathrm{NS}$ & $0.2627 \mathrm{NS}$ & $0.3892 \mathrm{NS}$ & $0.3855 \mathrm{NS}$ & $0.2209 \mathrm{NS}$ & $0.1447 \mathrm{NS}$ & $0.0505^{+}$ & $0.0179 *$ & $0.0076^{* *}$ & - & $0.0145^{*}$ \\
\hline \multicolumn{13}{|c|}{ Scion circumference $(\mathrm{cm})$} \\
\hline General mean & 1.7 & 4.9 & 7.8 & 113.0 & 17.8 & 22.8 & 27.3 & 30.8 & 34.2 & 38.0 & - & 42.8 \\
\hline Residual CV (\%) & 28.0 & 13.0 & 12.0 & 11.0 & 9.8 & 9.8 & 10.0 & 9.7 & 10.0 & 11.0 & - & 11.0 \\
\hline Mean amplitude ${ }^{y}$ & 0.6 & 0.9 & 2.2 & 2.7 & 4.8 & 5.7 & 6.8 & 7.6 & 9.4 & 11.3 & - & 14.1 \\
\hline$F$ Treatment prob $>F$ & $0.7592 \mathrm{NS}$ & $0.7005 \mathrm{NS}$ & $0.0413 *$ & $0.1587 \mathrm{NS}$ & $0.0014 * *$ & $0.0004 * * *$ & $0.0001 * * *$ & $<0.0001 * * *$ & $<0.0001 * * *$ & $<0.0001 * * *$ & - & $<0.0001 * * *$ \\
\hline$F$ Block prob $>F$ & $0.0252 \mathrm{NS}$ & $0.9480 \mathrm{NS}$ & $0.0399 *$ & $0.3119 \mathrm{NS}$ & $0.9557 \mathrm{NS}$ & $0.4369 \mathrm{NS}$ & $0.6459 \mathrm{NS}$ & $0.6459 \mathrm{NS}$ & $0.3510 \mathrm{NS}$ & $0.5806 \mathrm{NS}$ & - & $0.3736 \mathrm{NS}$ \\
\hline \multicolumn{13}{|l|}{ Annual yield (kg) } \\
\hline General mean & - & - & 2.43 & 7.79 & 25.4 & 23.5 & 54.1 & 61.1 & 60.8 & 40.7 & 63.7 & 63.6 \\
\hline Residual CV (\%) & - & - & 124 & 52 & 37 & 44 & 26 & 24 & 34 & 43 & 28 & 31 \\
\hline Mean amplitude ${ }^{\mathrm{y}}$ & - & - & 4.3 & 8.1 & 23.9 & 16.8 & 29.7 & 43.3 & 51.4 & 38.6 & 53 & 46.1 \\
\hline$F$ Treatment prob $>F$ & - & - & $0.5478 \mathrm{NS}$ & $0.0618 \mathrm{NS}$ & $0.0330 *$ & $0.2613 \mathrm{NS}$ & $0.0132 *$ & $<0.0001 * * *$ & $0.0023 * *$ & $0.0084 * *$ & $0.0002 * * *$ & $0.0040 * *$ \\
\hline$F$ Block prob $>F$ & - & - & 0.6914 NS & $0.4770 \mathrm{NS}$ & $0.3363 \mathrm{NS}$ & $0.1875 \mathrm{NS}$ & $0.5069 \mathrm{NS}$ & $0.5139 \mathrm{NS}$ & $0.5573 \mathrm{NS}$ & $0.1206 \mathrm{NS}$ & $0.0005 * * *$ & $0.0127 *$ \\
\hline \multicolumn{13}{|l|}{ Cumulative yield (kg) } \\
\hline General mean & - & - & 2.43 & 10.2 & 35.6 & 59.1 & 113.2 & 175.2 & 236.0 & 276.7 & 340.4 & 404.0 \\
\hline Residual CV (\%) & - & - & 124 & 55 & 37 & 35 & 27 & 21 & 22 & 22 & 21 & 21 \\
\hline Mean amplitude & - & - & 4.3 & 10.5 & 26.0 & 34.7 & 54.8 & 98.6 & 150.0 & 184.9 & 234.1 & 279.2 \\
\hline$F$ Treatment prob $>F$ & - & - & $0.5478 \mathrm{NS}$ & $0.0520 \mathrm{NS}$ & $0.0319 *$ & $0.0882 \mathrm{NS}$ & $0.0233 *$ & $0.0003 * * *$ & $0.0001 * * *$ & $<0.0001 * * *$ & $<0.0001 * * *$ & $<0.0001 * * *$ \\
\hline$F$ Block prob $>F$ & - & - & $0.6914 \mathrm{NS}$ & $0.5831 \mathrm{NS}$ & $0.3186 \mathrm{NS}$ & $0.4257 \mathrm{NS}$ & $0.6242 \mathrm{NS}$ & $0.5819 \mathrm{NS}$ & $0.5479 \mathrm{NS}$ & $0.0876 \mathrm{NS}$ & $0.0876 \mathrm{NS}$ & $0.0751 \mathrm{NS}$ \\
\hline
\end{tabular}

y Difference between smallest and largest means.

${ }^{\mathrm{z}}$ Significance: ${ }^{+} 0.1<P<0.05 ; * P \leq 0.05 ; * * P \leq 0.01 ; * * * P \leq 0.001 ;$ NS, no significant difference.

Table 4. Mean comparisons of growth and yield of Commune clementine grafted on Pomeroy trifoliate orange infected with single viroid sources ${ }^{\mathrm{w}, \mathrm{x}}$

\begin{tabular}{|c|c|c|c|c|c|c|c|c|c|c|c|}
\hline \multicolumn{2}{|c|}{ Treatment } & \multicolumn{2}{|c|}{ Height $(\mathrm{m})^{\mathrm{y}}$} & \multicolumn{2}{|c|}{$\begin{array}{c}\text { Rootstock } \\
\text { circumference }(\mathrm{cm})\end{array}$} & \multicolumn{2}{|c|}{$\begin{array}{l}\text { Scion circumference } \\
(\mathbf{c m})\end{array}$} & \multicolumn{2}{|c|}{ Annual yield (kg) } & \multicolumn{2}{|c|}{ Cumulative yield (kg) } \\
\hline Viroid $^{z}$ & Isolate & 1996 & 2001 & 1996 & 2001 & 1996 & 2001 & 1996 & 2001 & 1992-1996 & 1992-2001 \\
\hline \multirow{3}{*}{$\begin{array}{l}\text { Control } \\
\text { CEVd }\end{array}$} & & $2.88 \mathrm{ab}$ & $3.40 \mathrm{a}$ & $40.0 \mathrm{ab}$ & $75.1 \mathrm{a}$ & $29.6 \mathrm{ab}$ & $51.8 \mathrm{a}$ & $73.6 \mathrm{a}$ & $88.1 \mathrm{ab}$ & $134.1 \mathrm{a}$ & 570 \\
\hline & CEVd-117 & (*) $2.47 \mathrm{~b}$ & $3.09 \mathrm{ab}$ & (*) $33.8 \mathrm{c}$ & (*) $61.8 \mathrm{bcd}$ & $25.2 \mathrm{ab}$ & (*) $39.2 \mathrm{bc}$ & $44.2 \mathrm{a}$ & $42.7 \mathrm{~b}$ & $93.2 \mathrm{a}$ & (*) $291.1 \mathrm{c}$ \\
\hline & CEVd-129 & $2.61 \mathrm{ab}$ & $3.20 \mathrm{ab}$ & $36.2 \mathrm{abc}$ & $65.4 \mathrm{a}-\mathrm{d}$ & $25.9 \mathrm{ab}$ & (*) $39.7 \mathrm{bc}$ & $48.5 \mathrm{a}$ & $51.7 \mathrm{ab}$ & $94.1 \mathrm{a}$ & (*) $299.9 \mathrm{c}$ \\
\hline \multirow[t]{2}{*}{ CBLVd } & CVd-Ia-117 & $2.84 \mathrm{ab}$ & $3.26 \mathrm{ab}$ & $41.8 \mathrm{a}$ & $72.6 \mathrm{ab}$ & $30.8 \mathrm{a}$ & $48.2 \mathrm{abc}$ & $56.1 \mathrm{a}$ & $71.1 \mathrm{ab}$ & $130.0 \mathrm{a}$ & $498.5 \mathrm{ab}$ \\
\hline & CVd-Ib & $2.82 \mathrm{ab}$ & $3.29 \mathrm{ab}$ & $38.3 \mathrm{abc}$ & $69.8 \mathrm{a}-\mathrm{d}$ & $29.3 \mathrm{ab}$ & $47.1 \mathrm{abc}$ & $59.5 \mathrm{a}$ & $75.1 \mathrm{ab}$ & $120.6 \mathrm{a}$ & $465.0 \mathrm{abc}$ \\
\hline \multirow[t]{3}{*}{ HSVd } & CVd-IIa-117 & $2.92 \mathrm{a}$ & $3.31 \mathrm{a}$ & $38.1 \mathrm{abc}$ & $68.8 \mathrm{a}-\mathrm{d}$ & $30.8 \mathrm{a}$ & $48.3 \mathrm{ab}$ & $67.5 \mathrm{a}$ & $88.8 \mathrm{a}$ & $129.6 \mathrm{a}$ & $502.8 \mathrm{ab}$ \\
\hline & CVd-IIb & $2.79 \mathrm{ab}$ & $3.33 \mathrm{a}$ & $38.6 \mathrm{abc}$ & $67.2 \mathrm{a}-\mathrm{d}$ & $29.8 \mathrm{ab}$ & $46.9 \mathrm{abc}$ & $62.4 \mathrm{a}$ & $65.9 \mathrm{ab}$ & $140.6 \mathrm{a}$ & $458.8 \mathrm{abc}$ \\
\hline & CVd-IIc & $2.66 \mathrm{ab}$ & $3.21 \mathrm{ab}$ & $35.6 \mathrm{bc}$ & (*) $65.6 \mathrm{a}-\mathrm{d}$ & $26.8 \mathrm{ab}$ & $42.5 \mathrm{abc}$ & $53.5 \mathrm{a}$ & $61.1 \mathrm{ab}$ & $115.0 \mathrm{a}$ & (*) $377.6 \mathrm{abc}$ \\
\hline \multirow[t]{4}{*}{ CVd-III } & CVd-IIIa & $2.69 \mathrm{ab}$ & $3.05 \mathrm{ab}$ & (*) $34.9 \mathrm{bc}$ & (*) $60.0 \mathrm{~d}$ & (*) $24.3 \mathrm{~b}$ & (*) $37.9 \mathrm{bc}$ & $46.5 \mathrm{a}$ & $50.5 \mathrm{ab}$ & $94.5 \mathrm{a}$ & (*) $348.3 \mathrm{bc}$ \\
\hline & CVd-IIIb & $2.68 \mathrm{ab}$ & $3.02 \mathrm{ab}$ & $37.5 \mathrm{abc}$ & (*) $64.3 \mathrm{a}-\mathrm{d}$ & $25.6 \mathrm{ab}$ & (*) $37.7 \mathrm{c}$ & $50.3 \mathrm{a}$ & $68.1 \mathrm{ab}$ & $117.5 \mathrm{a}$ & $432.6 \mathrm{abc}$ \\
\hline & CVd-IIIc & $2.58 \mathrm{ab}$ & (*) $2.88 \mathrm{ab}$ & $36.7 \mathrm{abc}$ & (*) 63.9 a-d & (*) $24.0 \mathrm{~b}$ & (*) $38.9 \mathrm{bc}$ & $43.9 \mathrm{a}$ & $60.2 \mathrm{ab}$ & $92.9 \mathrm{a}$ & (*) $345.6 \mathrm{bc}$ \\
\hline & CVd-IIId & (*) $2.43 \mathrm{~b}$ & (*) $2.77 \mathrm{ab}$ & $36.3 \mathrm{abd}$ & (*) $60.9 \mathrm{~cd}$ & $26.5 \mathrm{ab}$ & (*) $38.7 \mathrm{bc}$ & $44.8 \mathrm{a}$ & $44.8 \mathrm{~b}$ & $89.6 \mathrm{a}$ & (*) $294.8 \mathrm{c}$ \\
\hline CVd-IV & CVd-IV-Ca & $2.91 \mathrm{a}$ & $3.35 \mathrm{a}$ & $38.1 \mathrm{abc}$ & $67.2 \mathrm{a}-\mathrm{d}$ & $30.1 \mathrm{ab}$ & $48.2 \mathrm{abc}$ & $64.8 \mathrm{a}$ & $82.1 \mathrm{ab}$ & $144.4 \mathrm{a}$ & $514.7 \mathrm{ab}$ \\
\hline
\end{tabular}

${ }^{\text {w }}$ Means within columns followed by the same letter do not differ significantly at $P \leq 0.05$ according to the Tukey HSD test.

${ }^{x}$ Means within columns preceded by (*) differ significantly from the control at $P \leq 0.05$ according to the Dunnett test.

y Since 1997, trees were pruned every year in order to open the canopy.

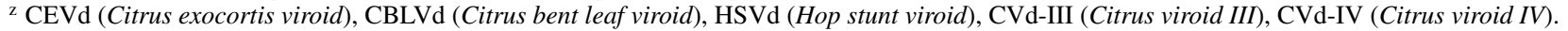


HSVd variants caused a reduction in annual production.

Cumulative yields among treatments (Fig. 3B) started to show highly significant differences in 1997 (Table 3). Cumulative yield ranged from 291.1 to $570.3 \mathrm{~kg}$ in 2001 for CEVd-117 and the control, respectively (Table 4). As a consequence, cumulative yields were $90 \%$ (CVd-IV) to about 50\% (CEVd-117) compared with the control. Both CEVd isolates caused significant reductions in cumulative yields, 49 and $47 \%$ for CEVd-117 and CEVd-129, respectively. All CVd-III isolates except $\mathrm{CVd}$-IIIb also caused important reductions in cumulative yields that were statistically significant according to Dunnett's test. CEVd and CVd-III treatments were clustered in the same group as defined by the Tukey HSD test even though the reductions induced by CEVd were more intense (Table 4). CBLVd and CVd-IV did not induce a significant effect compared with the control (Table 4). The cachexia isolates of HSVd caused reductions in cumulative yield (20 and 34\% for CVd-IIb and CVd-IIc, respectively), but these were statistically significant only for CVd-IIc according to the Dunnett test (Table 4).

In order to estimate the relationship between canopy size and decrease in annual and cumulative yields, the yield per canopy volume was evaluated (Table 5). The results indicate that $\mathrm{CEVd}$ caused important reductions of canopy volume; however, the cumulative yields per canopy volume in 2001 were $69 \%$ (CEVd-117) and $70 \%$ (CEVd-129) of those of the noninoculated control. CVd-III also caused important reductions of canopy volume which resulted in an increase of cumulative yield per canopy volume, only consistent in the case of CVd-IIIb.
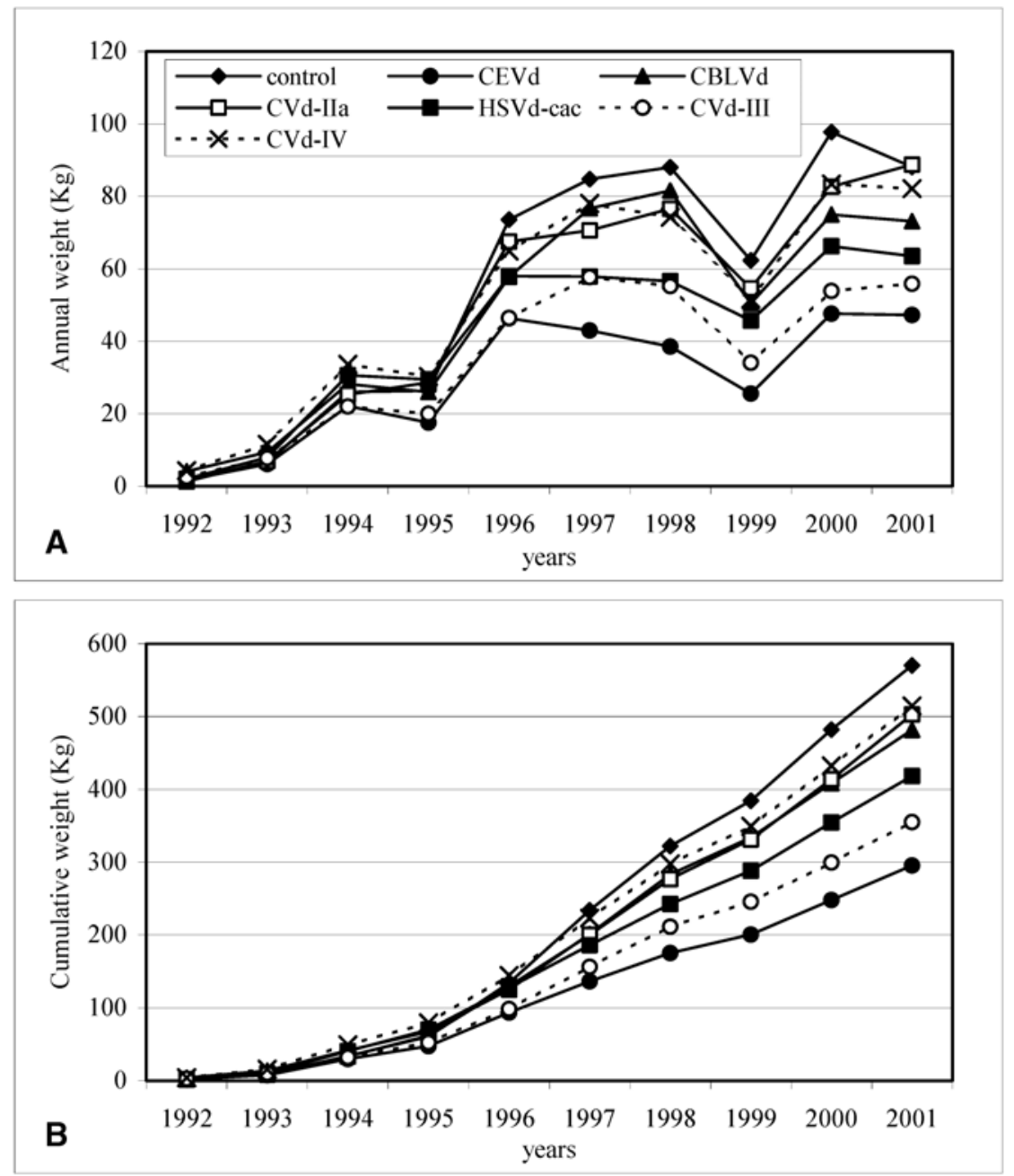

Fig. 3. Yield of Commune clementine grafted on trifoliate orange after infection with single viroids measured as: A, annual yield; and $\mathbf{B}$, cumulative yield. Curves represent the average of isolates of each viroid species. In the case of Hop stunt viroid (HSVd), cachexia isolates are represented separately (HSVd-cac is the average of isolates CVd-IIb and CVd-IIc) from the non-cachexia isolate CVd-IIa.

Table 5. Mean comparisons of canopy size and yield per canopy volume of Commune clementine grafted on Pomeroy trifoliate orange infected with a single viroid ${ }^{\mathrm{v}, \mathrm{w}}$

\begin{tabular}{|c|c|c|c|c|c|c|c|}
\hline \multicolumn{2}{|c|}{ Treatment } & \multicolumn{2}{|c|}{$\begin{array}{c}\text { Canopy volume } \\
\left(\mathbf{m}^{3}\right)\end{array}$} & \multicolumn{2}{|c|}{$\begin{array}{c}\text { Annual yield/volume } \\
\left(\mathbf{k g} / \mathbf{m}^{3}\right)\end{array}$} & \multicolumn{2}{|c|}{$\begin{array}{c}\text { Cumulative yield/volume } \\
\left(\mathrm{kg} / \mathrm{m}^{\mathbf{3}}\right)\end{array}$} \\
\hline Viroid $^{\mathrm{z}}$ & Isolate & 1996 & 2001 & 1996 & 2001 & 1996 & 2001 \\
\hline Control & & $7.85 \mathrm{ab}$ & $20.68 \mathrm{ab}$ & $9.09 \mathrm{a}$ & $3.91 \mathrm{a}$ & $16.59 \mathrm{a}$ & $27.21 \mathrm{ab}$ \\
\hline CEVd & $\begin{array}{l}\text { CEVd-117 } \\
\text { CEVd-129 }\end{array}$ & $\begin{array}{l}\text { (*) } 4.69 \mathrm{~b} \\
5.78 \mathrm{ab}\end{array}$ & $\begin{array}{l}15.55 \mathrm{ab} \\
15.21 \mathrm{ab}\end{array}$ & $\begin{array}{l}9.85 \mathrm{a} \\
8.56 \mathrm{a}\end{array}$ & $\begin{array}{l}2.72 \mathrm{a} \\
3.06 \mathrm{a}\end{array}$ & $\begin{array}{l}20.39 \mathrm{a} \\
16.56 \mathrm{a}\end{array}$ & $\begin{array}{l}18.89 \mathrm{~b} \\
19.04 \mathrm{~b}\end{array}$ \\
\hline CBLVd & $\begin{array}{l}\text { CVd-Ia-117 } \\
\text { CVd-Ib }\end{array}$ & $\begin{array}{l}7.35 \mathrm{ab} \\
7.51 \mathrm{ab}\end{array}$ & $\begin{array}{l}18.64 \mathrm{ab} \\
18.83 \mathrm{ab}\end{array}$ & $\begin{array}{l}7.46 \mathrm{a} \\
8.25 \mathrm{a}\end{array}$ & $\begin{array}{l}3.60 \mathrm{a} \\
4.12 \mathrm{a}\end{array}$ & $\begin{array}{l}17.60 \mathrm{a} \\
16.52 \mathrm{a}\end{array}$ & $\begin{array}{l}26.53 \mathrm{ab} \\
24.71 \mathrm{ab}\end{array}$ \\
\hline HSVd & $\begin{array}{l}\text { CVd-IIa-117 } \\
\text { CVd-IIb } \\
\text { CVd-IIc }\end{array}$ & $\begin{array}{l}8.52 \mathrm{a} \\
7.49 \mathrm{ab} \\
6.14 \mathrm{ab}\end{array}$ & $\begin{array}{l}20.30 \mathrm{ab} \\
19.45 \mathrm{ab} \\
17.35 \mathrm{ab}\end{array}$ & $\begin{array}{l}7.99 \mathrm{a} \\
9.13 \mathrm{a} \\
9.06 \mathrm{a}\end{array}$ & $\begin{array}{l}4.51 \mathrm{a} \\
3.48 \mathrm{a} \\
3.49 \mathrm{a}\end{array}$ & $\begin{array}{l}15.59 \mathrm{a} \\
19.66 \mathrm{a} \\
19.78 \mathrm{a}\end{array}$ & $\begin{array}{l}25.32 \mathrm{ab} \\
24.54 \mathrm{ab} \\
21.65 \mathrm{ab}\end{array}$ \\
\hline CVd-III & $\begin{array}{l}\text { CVd-IIIa } \\
\text { CVd-IIIb } \\
\text { CVd-IIIc } \\
\text { CVd-IIId }\end{array}$ & $\begin{array}{l}6.43 \mathrm{ab} \\
6.36 \mathrm{ab} \\
5.57 \mathrm{ab} \\
\text { (*) } 4.44 \mathrm{~b}\end{array}$ & $\begin{aligned} & 15.29 \mathrm{ab} \\
& 14.51 \mathrm{~b} \\
&(*) 12.69 \mathrm{~b} \\
& \text { (*) } 12.62 \mathrm{~b}\end{aligned}$ & $\begin{array}{r}7.21 \mathrm{a} \\
8.12 \mathrm{a} \\
8.03 \mathrm{a} \\
10.45 \mathrm{a}\end{array}$ & $\begin{array}{l}3.29 \mathrm{a} \\
4.74 \mathrm{a} \\
4.93 \mathrm{a} \\
3.61 \mathrm{a}\end{array}$ & $\begin{array}{l}14.75 \mathrm{a} \\
19.83 \mathrm{a} \\
16.93 \mathrm{a} \\
21.11 \mathrm{a}\end{array}$ & $\begin{array}{l}22.95 \mathrm{ab} \\
30.72 \mathrm{a} \\
27.79 \mathrm{ab} \\
22.83 \mathrm{ab}\end{array}$ \\
\hline CVd-IV & CVd-IV-Ca & $8.53 \mathrm{a}$ & $22.85 \mathrm{a}$ & $8.04 \mathrm{a}$ & $3.71 \mathrm{a}$ & $17.61 \mathrm{a}$ & $23.43 \mathrm{ab}$ \\
\hline
\end{tabular}

${ }^{\mathrm{v}}$ Means within columns followed by the same letter do not differ significantly at $P \leq 0.05$ according to the Tukey HSD test.

${ }^{w}$ Means within columns preceded by (*) differ significantly from the control at $P \leq 0.05$ according to the Dunnett test (bilateral test).

${ }^{x}$ Canopy volume was estimated as a sphere volume with $V=4 / 3 \pi R^{3}, R$ being the tree height $\mathrm{H} / 2$ in 2001 and $(\mathrm{H}-0.5) / 2$ in 1996 .

${ }^{y}$ Cumulative yield was calculated for the period 1992 to 1996 and 1992 to 2001 for the canopy volume estimated in 1996 and 2001, respectively.

${ }^{\text {z }}$ CEVd (Citrus exocortis viroid), CBLVd (Citrus bent leaf viroid), HSVd (Hop stunt viroid), CVd-III (Citrus viroid III), CVd-IV (Citrus viroid $I V)$. 
The yield reduction caused by $\mathrm{CEVd}$ and CVd-III infection was mostly due to a smaller production of larger fruits compared with the noninoculated control (Table 6). Both CEVd isolates reduced fruit production significantly for calibers 2 to 5 . Cumulative weights were smaller than the control for caliber 0-1 and small calibers 6 and 7-8, with some significant differences. CVd-III isolates reduced yield significantly compared with the control for greater calibers. Cachexia HSVd variants induced some significant differences compared with the control for the larger calibers, but no statistical difference was observed for calibers 5 to 8 . CBLVd and CVd-IV did not induce any significant difference whatever the caliber. When comparing the calibers as a percentage of cumulative weights, significant differences between the treatments were observed only for calibers $0-1$ and 5 (data not shown).

\section{DISCUSSION}

The symptoms induced by CEVd conformed exactly with the first description of the exocortis disease by Fawcett and Klotz (12) characterized by "narrow strips of out bark becoming dry, tending to separate from the inner live bark and slowly peeling off" and "marked dwarfing of trees on trifoliate stock". The longer incubation period required for symptom expression in trees infected with CEVd-129 that produced milder scaling than CEVd-117 is compatible with early observations suggesting the existence of various strains of the exocortis agent $(3,18)$. In the early years of the experiment, infected trees revealed the presence of bark cracking symptoms, which were later masked by the severe scaling symptoms. As reported earlier (43), even though scaling and cracking symptoms affected only the trifoliate orange rootstock, the overall tree was affected (reduction of vegetative growth and poor aspect of canopy) and yielded only a small harvest. Formation of bumps of the rootstock, clearly observed on the wood after removing the bark, was only associated with CEVd infection.

All the HSVd isolates induced bark cracking on the trifoliate orange rootstock, confirming earlier observations showing that bark cracking symptoms were not necessarily associated with scaling nor with CEVd infection (34). Only those isolates (CVd-IIb and CVd-IIc) previously characterized as cachexia-inducing agents caused the characteristic gum deposits in the bark and pitting on the stem of the clementine scion. These results show that, as demonstrated with other cachexiasensitive hosts $(30,31,43)$, only those HSVd isolates containing the specific sequence motif in the $\mathrm{V}$ domain cause the disease on clementine.

The results of this assay showed that bark cracking of trifoliate orange may be induced by CEVd, CVd-IV, and HSVd, but not by CBLVd or CVd-III. The induction of bark cracking symptoms as a result of HSVd infection had been previously reported on trees infected with a noncachexia isolate (CVd-IIa) (34). The results of the present study show that HSVd induced bark cracking symptoms regardless of the presence or absence of the se- quence motif in the $\mathrm{V}$ domain responsible for the induction of cachexia symptoms.

The presence of deep pits in the trifoliate orange rootstock was associated with CBLVd (CVd-Ib) infection (34); however, the results of the present assay indicate that this abnormality is commonly seen in the Pomeroy trifoliate orange rootstock and is not the result of viroid infection. Similarly, gummy pits containing gum pockets similar to the "woody pitting", "gum pocket", and "gummy pitting" disorders described earlier $(13,15,18,23,37)$ were observed in trees of all treatments, including the noninoculated controls. Therefore, the reported association of these symptoms with viroid infection (23) should be considered with caution until the putative viroid is fully characterized and Koch's postulates fulfilled. Another abnormality characterized by "finger imprint" or "trunk strangling" symptoms on the trifoliate orange rootstock reported to be associated with CVd-III infection (34) was not observed in any of the four CVdIII treatments used in the present assay. This is in agreement with other observations indicating that such symptoms were not persistent and disappeared after about 10 years (39).

Viroid infection affected vegetative growth as determined by the height and rootstock and scion circumferences. The effect was statistically significant in the case of CEVd and CVd-III infection and almost nil in the case of CVd-IV. These effects result in important reductions of canopy volumes, which are not statistically significant because of variability within

Table 6. Cumulative weight per fruit caliber from viroid-infected Commune clementine grafted on Pomeroy trifoliate orange from 1993 to 2000

\begin{tabular}{|c|c|c|c|c|c|c|c|c|}
\hline & & \multicolumn{7}{|c|}{ Cumulative weight (kg) 1993-2000 from each caliber } \\
\hline \multicolumn{2}{|c|}{ Fruit size (mm) } & $\begin{array}{c}\text { Cal. 0-1 } \\
\text { fruit }>63\end{array}$ & $\begin{array}{c}\text { Cal. } 2 \\
58<\text { fruit } \leq 63\end{array}$ & $\begin{array}{c}\text { Cal. } 3 \\
54<\text { fruit } \leq 58\end{array}$ & $\begin{array}{c}\text { Cal. } 4 \\
50<\text { fruit } \leq 54\end{array}$ & $\begin{array}{c}\text { Cal. } 5 \\
46<\text { fruit } \leq 50\end{array}$ & $\begin{array}{c}\text { Cal. } 6 \\
43<\text { fruit } \leq 46\end{array}$ & $\begin{array}{c}\text { Cal. 7-8 } \\
\text { fruit }<43\end{array}$ \\
\hline \multirow{5}{*}{\multicolumn{2}{|c|}{$\begin{array}{l}\text { General mean } \\
\text { Residual CV }(\%) \\
\text { Mean amplitude }{ }^{\mathrm{v}} \\
F \text { Treatment: prob }>F \\
F \text { Block: prob }>F\end{array}$}} & 23.8 & 41.3 & 55.0 & 87.6 & 70.0 & 30.1 & 25.6 \\
\hline & & 29 & 23 & 24 & 25 & 28 & 35 & 45 \\
\hline & & 21.4 & 32.6 & 41.8 & 65.8 & 51.1 & 21.8 & 26.9 \\
\hline & & $0.0010 * * \mathrm{w}$ & $<0.0001 * * *$ & $0.0002 * * *$ & $<0.0001 * * *$ & $<0.0001 * * *$ & $0.0107 *$ & $0.0172 *$ \\
\hline & & $0.0016 * *$ & $0.0480 *$ & $0.3748 \mathrm{NS}$ & $0.0591+$ & $0.0065 * *$ & $0.0211 *$ & $0.0134 *$ \\
\hline \multicolumn{9}{|c|}{ Treatment } \\
\hline \multicolumn{9}{|c|}{ Viroid $^{\mathrm{x}} \quad$ Isolate } \\
\hline \multirow{3}{*}{$\begin{array}{l}\text { Control } \\
\text { CEVd }\end{array}$} & & $36.9 \mathrm{a}^{\mathrm{y}}$ & $63.4 \mathrm{a}$ & $80.3 \mathrm{a}$ & $125.1 \mathrm{a}$ & $95.1 \mathrm{ab}$ & $40.4 \mathrm{a}$ & $32.8 \mathrm{ab}$ \\
\hline & CEVd-117 & $(*)^{\mathrm{z}} 23.3 \mathrm{abc}$ & (*) $33.8 \mathrm{bc}$ & (*) $42.9 \mathrm{bc}$ & (*) $62.5 \mathrm{~cd}$ & (*) $45.3 \mathrm{c}$ & (*) $18.7 \mathrm{a}$ & $13.9 \mathrm{~b}$ \\
\hline & CEVd-129 & $22.0 \mathrm{abc}$ & (*) $32.7 \mathrm{bc}$ & (*) $38.5 \mathrm{c}$ & (*) $59.2 \mathrm{~d}$ & (*) $47.0 \mathrm{bc}$ & $21.7 \mathrm{a}$ & $22.3 \mathrm{ab}$ \\
\hline \multirow[t]{2}{*}{ CBLVd } & CVd-Ia-117 & $29.2 \mathrm{abc}$ & $53.3 \mathrm{ab}$ & $68.2 \mathrm{abc}$ & $111.4 \mathrm{abc}$ & $96.4 \mathrm{a}$ & $37.6 \mathrm{a}$ & $33.9 \mathrm{ab}$ \\
\hline & CVd-Ib & $23.2 \mathrm{abc}$ & $47.3 \mathrm{abc}$ & $63.1 \mathrm{abc}$ & $102.3 \mathrm{a}-\mathrm{d}$ & $79.2 \mathrm{abc}$ & $37.1 \mathrm{a}$ & $27.9 \mathrm{ab}$ \\
\hline \multirow[t]{3}{*}{ HSVd } & CVd-IIa & $30.7 \mathrm{ab}$ & $51.8 \mathrm{ab}$ & $69.2 \mathrm{ab}$ & $108.4 \mathrm{abc}$ & $87.8 \mathrm{ab}$ & $34.8 \mathrm{a}$ & $26.4 \mathrm{ab}$ \\
\hline & CVd-IIb & (*) $21.8 \mathrm{abc}$ & (*) $40.0 \mathrm{abc}$ & $55.6 \mathrm{abc}$ & $101.8 \mathrm{a}-\mathrm{d}$ & $94.3 \mathrm{ab}$ & $39.7 \mathrm{a}$ & $40.8 \mathrm{a}$ \\
\hline & CVd-IIc & $30.0 \mathrm{ab}$ & (*) $41.7 \mathrm{abc}$ & (*) $52.6 \mathrm{abc}$ & (*) $77.2 \mathrm{a}-\mathrm{d}$ & $60.0 \mathrm{abc}$ & $26.1 \mathrm{a}$ & $19.6 \mathrm{ab}$ \\
\hline \multirow[t]{4}{*}{ CVd-III } & CVd-IIIa & (*) $15.6 \mathrm{c}$ & (*) $30.9 \mathrm{c}$ & (*) $46.4 \mathrm{bc}$ & (*) 79.0 a-d & $64.7 \mathrm{abc}$ & $28.0 \mathrm{a}$ & $25.6 \mathrm{ab}$ \\
\hline & CVd-IIIb & (*) $18.0 \mathrm{bc}$ & (*) $39.3 \mathrm{bc}$ & $59.0 \mathrm{abc}$ & $97.0 \mathrm{a}-\mathrm{d}$ & $76.8 \mathrm{abc}$ & $33.1 \mathrm{a}$ & $28.0 \mathrm{ab}$ \\
\hline & CVd-IIIc & $24.3 \mathrm{abc}$ & (*) $39.3 \mathrm{bc}$ & (*) $48.6 \mathrm{abc}$ & (*) $69.5 \mathrm{bcd}$ & (*) $52.6 \mathrm{abc}$ & $24.3 \mathrm{a}$ & $21.0 \mathrm{ab}$ \\
\hline & CVd-IIId & (*) $17.5 \mathrm{bc}$ & (*) $30.8 \mathrm{c}$ & (*) $41.9 \mathrm{bc}$ & (*) $63.8 \mathrm{~cd}$ & (*) $51.1 \mathrm{abc}$ & $22.7 \mathrm{a}$ & $18.2 \mathrm{ab}$ \\
\hline CVd-IV & CV-IV-Ca & $28.4 \mathrm{abc}$ & $51.4 \mathrm{abc}$ & $68.0 \mathrm{abc}$ & $114.6 \mathrm{ab}$ & $86.3 \mathrm{abc}$ & $36.9 \mathrm{a}$ & $30.7 \mathrm{ab}$ \\
\hline
\end{tabular}

$\mathrm{v}$ Difference between smallest and largest means.

${ }^{w}$ Significant difference at $+0.05<P<0.10, * P \leq 0.05, * * P \leq 0.01$ and $* * * P \leq 0.001$; NS = no significant difference.

${ }^{x}$ CEVd (Citrus exocortis viroid), CBLVd (Citrus bent leaf viroid), HSVd (Hop stunt viroid), CVd-III (Citrus viroid III), CVd-IV (Citrus viroid IV).

y Means within columns followed by the same letter do not differ significantly at $P \leq 0.05$ according to the Tukey HSD test.

${ }^{z}$ Means within columns preceded by $\left(^{*}\right)$ differ significantly from the control at $P \leq 0.05$ according to the Dunnett test. 
replicates. The results regarding the effect of CVd-III are in agreement with previous reports about the potential of using $\mathrm{CVd}$ III as "dwarfing factor" $(20,24,25,39,43)$.

Annual and cumulative yields were also affected as a result of viroid infection with patterns of annual fluctuation, probably due to the seasonal alternation phenomenon which is not uncommon in citrus production. As reported in the case of 'Valencia' sweet orange grafted on trifoliate orange (39), the yield per canopy volume was enhanced by three of the CVd-III isolates studied since reduction in total yield was less than the reduction in canopy volume. Unfortunately, fruit size was reduced, a feature that is undesirable in the case of clementines. Unlike the effect reported in 'Valencia' sweet orange grafted on trifoliate orange (39), the non-cachexia variant (CVd-IIa) of HSVd induced only a minor effect on vegetative growth and yield per canopy volume. A careful evaluation of costs and benefits should be made before using viroid infection as a strategy for controlling tree size.

Based on the results presented here as well as on previous studies $(20,24,25$, $39,44)$, we would like to propose the name Citrus dwarfing viroid (CDVd) to replace CVd-III, recommended by the International Committee on Taxonomy of Viruses (14). The new name is more descriptive because it refers to the only visible effect caused by CVd-III.

\section{ACKNOWLEDGMENTS}

This work was partially supported by grants SC97-108 and RTA01-119 from the Ministerio de Ciencia y Tecnología (Spain). The authors would like to thank Rosario Carbó for technical assistance and A. Olmos and R. Peñaler for their assistance with the figures. The authors also thank Jean Luc Ribouchon and Jean Gustave Borelli from SRA for skillful technical assistance and Marie Line Caruana and Serge Galzi from CIRAD, and Camille Jacquemond from SRA for helpful consultation and assistance.

\section{LITERATURE CITED}

1. Ben-Shaul, A., Guang, Y., Mogilner, N., Hadas, R., Mawassi, M., Gafny, R., and BarJoseph, M. 1995. Genomic diversity among populations of two citrus viroids from different graft-transmissible dwarfing complexes in Israel. Phytopathology 85:359-364.

2. Benton, R. J., Bowman, F. T., Fraser, L., and Kebby, R. G. 1949. Selection of citrus budwood to control scaly butt in trifoliata rootstock. Agric. Gaz. N. S. W. 60:31-34.

3. Benton, R. J., Bowman, F. T., Fraser, L., and Kebby, R. G. 1950. Stunting and scaly butt associated with Poncirus trifoliata rootstock. N. S. W. Dep. Agric. Sci. Bull. 70:1-20.

4. Calavan, E. C. 1968. Exocortis. Pages 23-34 in: Indexing procedures for 15 citrus diseases of citrus trees. U.S. Dep. Agric. Agric. Res. Serv. Agric. Handb. No. 33

5. Chaffai, M. 2001. Estudio de la tolerancia a distintas enfermedades asociada a infecciones con viroides. Tesis doctoral. Universidad de Valencia.

6. Childs, J. F. L. 1950. The cachexia disease of Orlando tangelo. Plant Dis. Rep. 34:295-298.

7. Diener, T. O., Smith, D. R., Hammond, R. H., Albanese, G., La Rosa, R., and Davino, M. 1988. Citrus B viroid identified as a strain of hop stunt viroid. Plant Dis. 72:691-693.
8. Duran-Vila, N., Flores, R., and Semancik, J. S. 1986. Characterization of viroid-like RNAs associated with the citrus exocortis syndrome. Virology 150:75-84.

9. Duran-Vila, N., Pina, J. A., Ballester, J. F., Juárez, J., Roistacher, C. N., RiveraBustamante, R., and Semancik, J. S. 1988. The citrus exocortis disease: A complex of viroid RNAs. Pages 152-164 in: Proc. Conf. Int. Org. Citrus Virol. 10th. IOCV, Riverside, CA

10. Duran-Vila, N., Roistacher, C. N., RiveraBustamante, R., and Semancik, J. S. 1988. A definition of citrus viroid groups and their relationship to the exocortis disease. J. Gen. Virol. 69:3069-3080.

11. Duran-Vila, N., and Semancik, J. S. 1990. Variations on the "cross protection" effect between two strains of citrus exocortis viroid. Ann. Appl. Biol. 17:367-377.

12. Fawcett, H. S., and Klotz, L. J. 1948. Exocortis on trifoliate orange. Citrus Leaves 28:8

13. Fernández-Valiela, M. V., Fortugno, C., and Corizzi, F. 1965. Incidence of bud-union crease in citrus trees grafted on trifoliata rootstock in the Delta del Paraná and San Pedro areas of Argentina. Pages 182-186 in: Proc. Conf. Int. Org. Citrus Virol. 3rd. IOCV, Riverside, CA

14. Flores, R., Randles, J. W., Bar-Joseph, M., and Diener, T. O. 2000. Subviral agents: Viroids. Pages 1009-1024 in: Virus Taxonomy, Seventh Report of The International Committee on Taxonomy of Viruses. Academic Press, San Diego, CA.

15. Foguet, J. L., and Oste, C. A. 1968. Disorders of trifoliate orange rootstock in Tucumán, Argentina. Pages 183-189 in: Proc. Conf. Int. Org. Citrus Virol. 4th. IOCV, Riverside, CA.

16. Foissac, X., and Duran-Vila, N. 2000. Characterization of two citrus apscaviroids isolated in Spain. Arch. Virol. 145:1975-1983.

17. Francis, M., Szychowski, J. A., and Semancik, J. S. 1995. Structural sites specific to citrus viroid groups. J. Gen. Virol. 76:1081-1089.

18. Fraser, L. R., and Levitt, E. C. 1959. Recent advances in the study of exocortis (scaly butt) in Australia. University of California Div. Agric. Sci., Riverside. pp. 129-133.

19. Gandía, M., Palacio, A., and Duran-Vila, N. 1998. Variability of citrus exocortis viroid (CEVd). Pages 289-293 in: Proc. Conf. Int. Org. Citrus Virol. 14th. IOCV, Riverside, CA.

20. Gillings, M. R., Broadbent, P., and Gollow, B. I. 1991. Viroids in Australian Citrus: Relationship to exocortis, cachexia and citrus dwarfing. Aust. J. Plant Physiol. 18:559-570.

21. Hataya, T., Nakahara, K., Ohara, T., Ieki, H., and Kano, T. 1998. Citrus viroid Ia is a derivative of citrus bent leaf viroid (CVd-Ib) by partial sequence duplications in the right terminal region. Arch. Virol. 143:971-980.

22. Ito, T., Ieki, H., Ozaki, K., and Ito, T. 2001. Characterization of a new citrus viroid species tentatively termed citrus viroid OS. Arch. Virol. 146:975-982.

23. Marais, L. J., Lee, R. F., Breytenbach, J. H. J., Manicom, B. Q., and Vanvuuren, S. P. 1996. Association of a viroid with Gum Pocket disease of trifoliate orange. Pages 236-244 in: Proc. Conf. Int. Org. Citrus Virol. 13th. IOCV, Riverside, CA.

24. Owens, R. A., Thompson, S. M., Feldstein, P. A., and Garnsey, S. M. 1999. Effects of natural sequence variation on symptom inducion by citrus viroid III. Ann. Appl. Biol. 134:73-80.

25. Owens, R. A., Yang, G., Gundersen-Rindal, D., Hammond, R. W., Candresse, T., and BarJoseph, M. 2000. Both point mutations and RNA recombination contribute to the sequence diversity of citrus viroid III. Virus Genes 20:243-252.

26. Palacio-Bielsa, A., Foissac, X., and DuranVila, N. 2000. Indexing of citrus viroids by imprint hybridisation. Eur. J. Plant Pathol. 105:897-903
27. Palacio-Bielsa, A., Romero-Durbán, J., and Duran-Vila, N. 2004. Characterization of citrus HSVd isolates. Arch. Virol. 149:537-552.

28. Puchta, H., Ramm, K., Luckinger, R., Hadas, R., Bar-Joseph, M., and Sänger, H. L. 1991 Primary and secondary structure of citrus viroid IV (CVd IV), a new chimeric viroid present in dwarfed grapefruit in Israel. Nucleic Acids Res. 19:6640.

29. Rakowski, A. G., Szychowski, J. A., Avena, Z. S., and Semancik, J. S. 1994. Nucleotide sequence and structural features of the Group III citrus viroids. J. Gen. Virol. 75:3581-3584

30. Reanwarakorn, K., and Semancik, J. S. 1998. Regulation of pathogenicity in hop stunt viroid related group II citrus viroids. J. Gen. Virol. 79:3163-3171.

31. Reanwarakorn, K., and Semancik, J. S. 1999. Correlation of hop stunt viroid variants to cachexia and xyloporosis diseases of citrus. Phytopathology 89:568-574.

32. Reichert, I., and Perlberger, P. 1934. Xyloporosis, the new citrus disease. Hadar 7:163-167, 172, 193-202.

33. Rivera-Bustamante, R. F., Gin, R., and Semancik, J. S. 1986. Enhanced resolution of circular and linear molecular forms of viroid and viroidlike RNA by electrophoresis in a discontinuouspH system. Anal. Biochem. 156:91-95.

34. Roistacher, C. N., Bash, J. A., and Semancik, J. S. 1993. Distinct disease symptoms in Poncirus trifoliata induced by three citrus viroids from three specific groups. Pages 173-179 in: Proc. Conf. Int. Org. Citrus Virol. 12th. IOCV, Riverside, CA.

35. Roistacher, C. N., Calavan, E. C., Blue, R. L., Navarro, L., and Gonzales, R. 1977. A new more sensitive citron indicator for the detection of mild isolates of citrus exocortis viroid (CEV). Plant Dis. Rep. 61:135-139.

36. Schlemmer, A., Roistacher, C. N., and Semancik, J. S. 1985. A unique, infectious RNA associated with citron showing symptoms typical of citrus exocortis disease. Phytopathology 75:946-949.

37. Schwarz, R. E., and McClean, A. P. D. 1969. Gum-pocket, a new virus-like disease of Poncirus trifoliata. Plant Dis. Rep. 53:336-339.

38. Semancik, J. S., Morris, T. J., Weathers, L. G., Rodorf, G. F., and Kearns, D. R. 1975. Physical properties of a minimal infectious RNA (viroid) associated with the exocortis disease. Virology 63:160-167.

39. Semancik, J. S., Rakowski, A. G., Bash, J. A., and Gumpf, D. J. 1997. Application of selected viroids for dwarfing and enhancement of production of "Valencia" orange. J. Hortic. Sci. 72:563-570.

40. Semancik, J. S., Roistacher, C. N., RiveraBustamante, R., and Duran-Vila, N. 1988. Citrus cachexia viroid, a new viroid of citrus: Relationship to viroids of the exocortis disease complex. J. Gen. Virol. 69:3059-3068.

41. Semancik, J. S., and Weathers, L. G. 1972. Exocortis disease: Evidence for a new species of "infectious" low molecular weight RNA in plants. Nature New Biol. 237:242-244.

42. Semancik, J. S., and Weathers, L. G. 1972. Exocortis virus: An infectious free-nucleic acid plant virus with unusual properties. Virology 46:456-466.

43. Vernière, C., Botella, L., Dubois, A., Chabrier, C., and Duran Vila, N. 2002. Properties of citrus viroids: Symptom expression and dwarfing. Pages 240-248 in: Proc. Int. Org. Citrus Virol. IOCV, Riverside, CA.

44. Villalobos, W., Rivera, C., and Hammond, R. W. 1997. Occurrence of citrus viroids in Costa Rica. Rev. Biol. Trop. 45:983-987.

45. Visvader, J. E., and Symons, R. H. 1986. Replication of in-vitro constructed viroid mutants: Location of the pathogenicitymodulating domain of citrus exocortis viroid. EMBO J. 5:2051-2055. 